URL: http://dergipark.ulakbim.gov.tr/ijhbs/index

Volume: 2, Issue: 2, Year: 2016

DOI: http://dx.doi.org/10.19148/ijhbs.65987

\title{
Parental Involvement and School Achievement
}

\author{
Ercan Kocayörük \\ Çanakkale Onsekiz Mart University, Turkey \\ ercankocayoruk@gmail.com
}

\begin{abstract}
Parents' involvement in their children's schooling is associated with children's school success, with the positive effects of parent involvement having now been demonstrated. Many researchers have emphasized that family or parental involvement is essential to ensure healthy child development such as cognitive, intellectual development, academic achievement and psychological adjustment in school settingsThere is a growing body of literature considering on parental involvement in education and this study has been focused on the effects of parental involvement that have the strongest relation with achievement and how the parents can be more involved in school activities. The current study conducted a review and discussion on parental involvement in education and school activities how and which types of parental involvement are related to achievement.
\end{abstract}

Key Words: academic achievement, parental involvement, school adjustment

\section{Introduction}

The family has long been recognized as the primary support system and socializing institution for children; the better the family operates, the more likely that a child will develop in a healthy manner. Smith, Perou and Lesesne (2002) claimed that the quality relationship between parents and their children was one of the most powerful issues in child development. Furthermore, relationships in families where the amount of time individuals spend time with other member of family and the impact that the family has on preparing the children for adolescents and adult life.

Parents' childrearing strategies, skills and behaviors embody and influence their children development. It is considered that the kind of parenting appears to promote optimal child development and to provide such developmental care in different period time. In the infancy period, growing literature in empirical studies reveals that cognitive-motivational competence and healthy psychosocial development are promoted by attentive, warm, stimulating, responsive and nonrestrictive parenting skills (Volling \& Belsky, 1991). During the preschool years high levels of parenting and control foster the ability to engage peers and adults in a friendly and cooperatively manner (Ahmeduzzaman \& Roppnarine, 1992). As children grow older, parental use of induction or reasoning, consistent disciplining and expression of warmth have been found to relate positively to self-esteem, internalized controls, prosocial orientation, and intellectual achievement during the early adolescent (Conger \& Galambos, 1997). . Namely, the available research studies suggest that involved parents who are warm, supportive and consistent in their behavior and style of discipline can effectively support the child and adolescent development. Children would benefit by having a close and involved relationship with both their mother and father. In general, parental involvement is crucial in preventing achievement and educational problems as well as facilitating children's development.

Schools also contribute to children's development and socialization in many aspects. Children can learn many skills and ideas from the schools. Main objective of schools is to contribute to the total development of children. Academic development is only a part of it. In 
order to achieve the other areas of development, the schools should work with parents in coordination. Partnership between home and school then creates the home-school consistency, which has been considered as very important in child development. Effective family-school partnership has been emphasized as a main force in supporting the adjustment of children to school (Keith, Keith, Troutman, Bickley, Trivette, \& Singh, 1993). Raffaele and Knoff (1999) stated that home-school collaboration appeared to be particularly important for children who had some risk factors such as economic impoverishment, limited parental training, and stressful home situations. They also pointed out that home-school collaboration seemed least likely to occur without systematic planning.

The importance of establishing effective home-school partnership is supported conceptually by Bronfenbrenner's ecological theory for understanding child behavior and individual differences in development. The ecological theory provides a conceptual framework for parents' involvement in educational process and parent training. It provides a framework that can be used to predict parenting processes and child outcomes by analyzing different settings in which the children and their caregivers function (Bronfenbrenner, 1979). In accordance with Bronfenbrenner's ecological framework, factors within the broader 'ecology' (person, family, school) of the environment in which children are brought up which have been found to be related to child mental health outcomes were also taken into account His ecological theory of human development model attempt to describe markers of interpersonal social and environmental multi-systemic influences on adolescent development. Bronfenbrenner (1989) conceptualizes the environmental context of development as consisting of four level or systems. First, the microsystem is that each individual develops within the context of multiple microsystems. For most individuals, the family is the first and most important microsystem. As development proceeds through childhood and into adolescence, additional microsystem becomes increasingly important. The two influential microsystem outside the family are the school and peer system. Second, the mesosystem highlight the importance of the multiple roles an individual must take to succeed within the multiple microsystem in which he/she develops. Although the family is the principal context in which human development takes place, it is but one of several settings in which developmental process can and do occur. Events at home can affect the child's progress in school, and vice versa. In addition, an adolescent may feel pressure to take on the role of son or daughter, friends, student, teammate. Third, such environments "external" to the developing person are referred to as "exosystems". While the adolescent is an active participant in the microsystem and mesosytem, the exosystem represent salient environmental influences on which the adolescent does not generally have a direct impact. Although individual may impact their family, peers and classroom, they are less likely to have an impact on exosystem such as parental employer, the school board, and the local government. Fourth and the final system is macrosytem that is embedded within a fifth system, the chronosystem and has a powerful impact on all system levels described previously. The simplest form of chronosystem focuses around a life transition. Bronfenbrenner (1989) stated two types of transition that were usefully distinguished: normative (school entry, puberty, entering the labor force, marriage, retirement) and nonnormative (a death or severe illness in the family, divorce, moving, winning the sweepstakes). Such transitions occur throughout the life span and often serve as a direct impetus for developmental change. Their relevance for the present review, however, lies in the fact that they can also influence this development indirectly by affecting family processes. In addition, each of the systems is interdependent, whereby a change in any of the systems influences all other systems. Inclusion of the choronosystem indicates that the nature of each system and the interactions between systems change over time (Bronfenbrenner, 1989).

Bronfenbrenner's model predicts that high levels of parent involvement in schools should lead to successful child outcomes. According to the theory, understanding child's behavior requires examination of four levels in the model, two in which the child directly participates (microsystem and mesosystem), and two in which the child does not directly participate but he/she is affected (exosytem and macrosystem). According to circular causality principle of the 
ecological model, school difficulties affect child's behavior in the family and family problems influence student's achievement and behavior in school. It could be stated that the ecological theory provides a support for understanding and enhancing the reciprocal influences of home and school.

\subsection{The Effect of Parent involvement on School}

There are many advantages when parents play an active role in the educational process. Children spend much more time at home than school. However, home environment is more familiar and intimate for the child than the school environment, since there is more chance to have one to one relationships. Therefore, achieving home-school consistency and information exchange between parties can be seen as important for academic, personal, and social development of children.

An impressive amount of research has been carried out that parent involvement is essential to ensure healthy child development, cognitive, intellectual development, academic achievement and psychological adjustment in school settings (Veneziano \& Rohner, 1998; Nord \& Brimhall, 1998; Mazza, 2002). While parent involvement such as attending a parentteacher conference, volunteering at school, helping with homework, or simply encouraging student achievement, provides an opportunity for children to gain more achievement, to improve school attendance and increase cooperative behavior, it enriches school retention (Balli, Demo \& Wedman, 1998). Wanat (1997) conducted a study with parents who were actively involved with their child's education. Her study conceptualized parent involvement in school from the perspectives of parents, and parents reported that parental involvement helped to increase learning, helped to shape kid's attitudes toward school, helped to build selfesteem, and helped children to take school seriously. Parents who are highly involved in their children's schools are more likely to be involved at home, as well. It was indicated by the empirical evidences that elementary school children with fathers or mothers who are highly involved in their schools are more likely to have participated in educational activities with their parents than children whose parents have low levels of involvement in their schools (Nord \& Brimhall, 1998). Thus, parent who are less involved and affectionate with their children are more likely to experience many more academic and behavioral problems with those children as they grow in years (Griffith, 1996).

It is clear that one of the most crucial issues of the literature relating parental involvement is to assist children in becoming more successful in the school by increasing family involvement in addressing specific barriers to learning. It is stated in the literature that parental involvement has an important positive and direct influence on student academic performance (Wanat, 1997). In other words, parents involved with their children's learning have important consequences for how children approach and engage in learning and academic achievement (Ames, Khoju \& Watkins, 1993). Several researchers have investigated the empirical relation between parental involvement and student academic performance. For instance, Phillips (1992) focused on parental involvement and children's education, and described the parental involvement to student achievement in school in three main areas: (a) education at home, both directly and indirectly; (b) socialization, including discipline, parental aspirations and beliefs, and cultural influences: and (c) formal parent-school involvement, so it is important that families are given to opportunity to be more involved in their children's education both at home and at school. In his study Reynolds (1992) collected data from parents, teachers and students regarding perceptions of parental involvement. Teacher perceptions of parental involvement had the highest correlations with student achievement; whereas parent and student perceptions had the lowest correlations with the student achievement. An earlier study showed similar relations between parental involvement and student academic achievement, and researchers found a positive relation between parental involvement and the student school performance in a sample of a 179 grade school children, parents and teachers (Stevenson, \& Baker, 1987).

It is inevitably that the difficulties experienced by families seem to be expressed in the rapidly increasing numbers of school dropouts and at-risk students. There are many studies in 
the literature demonstrating attempts to actually encourage parental involvement to reduce adolescent risk taking. For instance, Levendosky, Huth-Bocks and Samel (2002) emphasized that adolescence is very important and vulnerable stage in life span, in fact that these are generally the years when young people must deal with the first time with the issues of alcohol and drug use, with their emerging sexuality, and with strong peer pressure. With the potential influence in the early life of adolescent, parents who can maintain healthy and effective communication with their children can significantly support their children in dealing with the pressure of such kind of and other difficult aspects of growing up (Krappman \& Uhlendorf, 1999). Insufficient and ineffective parental involvement with their children has received a great deal of attention as a correlate to adolescent risk taking. The available research suggests that involved parents who are warm, supportive, and consistent in their behavior and style of discipline can effectively reduce the probability that their child/adolescent will engage in risktaking behaviors. For instance, quality family relationships have been consistently found to be important predictors of adolescent problem behaviors, including smoking, other substance use and alcohol use (Coker, \& Borders, 2001). Dysfunctional family structure, inadequate parenting skills, and lack of parental attention are strongly associated with the adolescent's selection of substance-using friends and with the tendency (Hindelang, Dwyer, \& Leeming, 2001). Ackard and his colleagues (2006) stated that adolescents' perceptions of low parental caring, difficulty talking to their parents about problems and valuing their friends' opinions for serious decisions were significantly associated with compromised behavioral and emotional health. These factors combined with the elevated rate of divorce, increased numbers of singleparent families and dual-career families, other sharply changing elements affecting families make some type of training for parents imperative.

\subsection{How parental involvement can be improved?}

There are potentially many ways in which positive school-family linkages could lead to successful child outcomes. Balli, Demo, and Wedman (1998) suggest that children may observe that caring teachers and parents are investing time and resources to help them succeed in school. Staff members may provide support and information about parenting and child development (Houge, Liddle, Becker\& Johson-Leckron, 2002) and also may serve as models of effective communication and involvement with young children. Supportive links between families and school are facilitated by frequent parental involvement in the child's program and communication with teachers.

Three main characteristics of the relationship between the school and the families can be depicted. First, schools can encourage and support greater family involvement in education. Research shows that when families take an active, direct role in their children's education, children get better grades and test scores, graduate from high school at higher rates ( Ames, Khoju \& Watkins, 1993). Second, schools should be places where families feel welcome and valued. School programs that encourage greater parental involvement are more important that any other factor in determining whether or not parents actually do get involved. Facilitating this involvement requires a good communication and collaboration between school and families. Schools might also encourage parents, teachers, and students to meet at the beginning of the school year to agree on goals and develop a common understanding. In fact, it can make a difference in student's achievement at school and in their healthy development when school sponsors family involvement initiatives and activities and to improve student learning and to support effective school performance through family-school partnership. Some schools make a special effort to help low-income families get involved because many of these families wait for the school to approach them (Colbert, 1996). Last and third issue is that Parents and families can support their schools and play their part at home. Hogue, Liddle, Becker and JohsonLeckron, (2002) outlined that parental involvement can take many forms, including getting involved in PTA activities; discussing children's progress with teachers on a regular basis; 
checking homework every night; reading to preschoolers; encouraging students to take the challenging courses.

Epstein and Salinas (1993) outlined the six types of partnerships to determine the teachers and parents' perceptions of practices between family and schools. The six types of partnership activities were (a) parenting skills, understanding of child development, home conditions for learning, and the school's understanding of its families; (b) communications from school to home and from home to school about programs and student progress; (c) the organization, schedules, and use of volunteers at and for the school, and the opportunities and schedules for audiences at school for student events; (d) family involvement in learning activities at home, including homework, class work, curriculum-related interactions, and decisions; (e) family involvement in school decisions, committees, school-based management, advocacy, and other practices of participation; and (f) community collaborations and resources for students, for the school, and for families.

Similarly, Gestwicki (2004) revealed that identifies six types f parent involvement activities. She stated that many schools have been following this model currently. The model includes:

-Parenting: This function includes helping families with parenting, child rearing skills, developmental knowledge, creating supporting conditions at home.

-Communicating: School communicates with parents through notices, conferences, newsletters, phone-calls, electronic messages. The topics of this communication mainly include school programs and student progress.

-Volunteering: This type includes schools' effort to involve families in school programs and in supporting students as volunteers.

-Learning at home: Schools involve families by giving learning activities for home, including homework and other curriculum related activities.

-Decision-making: Schools include families as participants in school decisions, different committees, advisory councils.

-Collaborating with the community: Schools' effort to coordinate services and resources for families and the school, as well as schools' contribution to the community through services.

In conclusion, partnership between home and school then creates the home-school consistency, which has been considered as very important in child development. The results of the many studies suggested that link parent involvement with a range of positive student outcomes, including higher achievement, improved school attendance, increased cooperative behavior, enhanced school retention and lower dropout rates (Balli, Demo \& Wedman, 1998; Epstein, 2001). Effective family-school partnership has been emphasized as a main force in supporting the adjustment of children to school (Keith, Keith, Troutman, Bickley, Trivette, \& Singh, 1993). Authors (Epstein, 2001; Hidelang, Dwyer, \&. Leeming, 2001) suggest that researchers interested in school-based programs to increase parental involvement in areas such as academic achievement, social development and prevention the risk-taking behaviors should begin by attempting to involve parents with their children's schoolwork from kindergarten to high school. 


\section{References}

Ahmeduzzaman, M., \& Roopnarine, J. (1992). Sociodemographic factors, functioning style, social support, and fathers' involvement in African American intact families. Journal of Marriage and the Family, 54, 699-707.

Ames, C., Khoju, M., \& Watkins, T. (1993). Parent involvement: The relationship between school to home communication and parents' perceptions and beliefs. Boston, MA: Center on Families, Communities, Schools \& Children's Learning.

Atkins, M. S., Hoagwood, K. E., Kutash, K. \& Seidman, E. (2010). Toward the Integration of Education and Mental Health in Schools. Administration and Policy, 37(1-2), 40-47. Retrieved October 05, 2011, from Springer database (http//www.springer.com).

Balli, J. S., Demo, H. D., \& Wedman, F. J. (1998). Family involvement with children's Homework: An intervention in the middle grades. Family Relations, 47(2), 149157.

Bronfenbranner, U. (1979). The ecology of human development. Experiment by nature and design. Boston: Harvard University Press.

Bronfenbrenner, U. (1989). Ecological systems theory. In R. Vasta (Ed.), Annals of child development, 6 (pp. 187-249). Greenwich, CT: JAI Press.

Christenson, S. L., \& Sheridan, S. M. (2001). School and families: Creating essential connections for learning. New York: Guilford Press.

Coker, J. K., \& Borders, L. D. (2001). An analysis of environmental and social factor affecting adolescent problem drinking. Journal of Counseling and Development, 79, 200-208.

Colbert, R. D. (1996). The counselor's role in advancing school and family partnerships. The School Counselor, 44, 100-104.

Comer, J. P. (1995). School power: Implications of an intervention project. New York: Free Press.

Conger, J. J., \& Galambos N. L. (1997). Adolescents and youth. Psychological development in a changing world. New York; Addison Wesley Longman.

Conners, L. J., \& Epstein, J. L. (1995). Parents and school partnerships. In M. H. Bornstein (Ed.), Handbook of parenting, 4, 437-458. Hillsdale, NJ: Erlbaum.

Epstein, J. L. (1987). Toward a theory of family-school connections: Teacher practices and parent involvement. In K. Hurrelman, F. X. Kaufman, \& F. Losel (Eds.), Social intervention: Potential and constraints (pp. 121-136). Berlin, Germany: de Gruyer.

Epstein, J. L. (2001). School, family, and community partnerships: Preparing educators and improving schools. Boulder, $\mathrm{CO}$ : Westview.

Epstein, J. L., \& Salinas, K. C. (1993). School and family partnerships: Surveys and summaries. Baltimore: Johns Hopkins University, Center on Families, Communities, Schools and Children's Learning.

Epstein, J. L., \& Sanders, M. G. (2002). Family, school, and community partnerships. In M. H. Bornstein (Ed.), Handbook of parenting: Vol. 5. Practical issues in parenting (pp. 507-437). Mahwah, NJ: Erlbaum.

Gestwicki, L. (2004). Home, school and community relations; a guide to working with families. New York; Thomson Delmar Learning.

Griffith, J. (1996). Relationship of parental involvement, empowerment, and school traits to students academic achievement. Journal of Educational Research,90(1), $33-41$. 
Hindelang, R. L., Dwyer, W. O., \&. Leeming, F. C. (2001). Adolescent risk-taking behavior: a review of the role of parental involvement. Curr. Probl. Pediatr, 31, 67-83.

Hogue, A., Liddle H. A., Becker D., \& Johnson-Leckrone, J. (2002). Family-based prevention counseling for high-risk young adolescents: immediate outcomes. Journal of Community psychology, 30(1), 1-22.

Keith, ' T. Z., Keith, P. B., Troutman, G. M., Bickley, P., Trivette, P. S., \& Singh, K. (1993). Does parental involvement affect eighth grade student achievement? Structural analysis of national data. School Psychology Review, 22, 474-496.

Krappman, L. \& Uhlendorff, H. (1999). Family influence on children's peer relationship: Parents' social networks and educational attitudes. Poster presented at the Bienal Meeting of the Society for Research in Child Development (Albuqeurque, NM, April 15-18, 1999). Retrieved February 9, 2006 from (An ERIC Digests: ED435496).

Levendosky, A. A., Huth-Bocks, A., \& Semel, M. A. (2002). Adolescent peer relationships and mental health functioning in families with domestic violence. Journal of Clinical Child and Adolescent Psychology 31, 206-218.

Mazza, C. (2002). Young Dads: The effects of a parenting program on urban AfricanAmerican adolescent fathers. Adolescence, 37, 148, 681-694.

Nord, W. C., \& Brimhall, D. (1998). Dad's involvement in their kid's school's. Education Digest, 63(7), 29-36.

Pelco, L. E., Ries, R. R., Jacobson, L., \& Melka, S. (2000). Perspectives and practices in family-school partnerships: A national survey of school psychologists. School Psychology Review, 29, 235-250.

Phillips, L. (1992). Parent involvement: Relationships of expectations, goals, and activities to student achievement among minority, socioeconomic, and gender groups. Paper presented at the annual meeting of the American Educational Research Association, San Francisco, CA. (ERIC Abstract).

Raffaele, L., \& Knoff, H. M. (1999). Improving home-school collaboration with parents of children at-risk: Organizational principles, perspectives, and approaches. School Psychology Review, 28, 448-466.

Reynolds, A. J. (1992). Grade Retention and School Adjustment: An Explanatory Analysis. Educational Evaluation and Policy Analysis, 14(2), 101-121.

Smith, C., Perou, R., \& Lesesne (2002). Parent education. In M. H. Bornstein (Ed.), Handbook of Parenting. Social conditional and applied parenting. Lawrence Erlbaum Associates. Publishers.

Stevenson, D. L., \& Baker, D. P. (1987). The family-school relation and the child's school performance. Child Development, 58, 1348-1357.

Veneziano, R. A., \& Rohner, R. P. (1998). Perceived paternal acceptance, paternal involvement, and youth's psychological adjustment in a rural biracial southern community. Journal of Marriage \& Family, 60(2), 335-344.

Volling B. L., \& Belsky, J. (1991). Multiple determinants of father involvement during infancy in dual-earner and single-earner families. Journal of Marriage and the Family, 53(February), 461-474.

Wanat, C., L. (1997). Conceptualizing parental involvement from Parents' Perspective: A case study. Caring Education, 3(4), 433-458. 